\title{
Myelopathy secondary to human T-lymphotropic virus and Treponema pallidum infection: case report
}

\author{
Pilar Enríquez-Ruano ${ }^{1,2} \cdot$ Cristian Eduardo Navarro $\mathbb{1}^{1,2} \cdot$ Michael Ariza-Varón ${ }^{1,2} \cdot$ Andrea del Pilar Calderón-Castro ${ }^{1,2}$
}

Received: 24 September 2019 / Revised: 26 October 2019 / Accepted: 27 October 2019

(c) International Spinal Cord Society 2019

\begin{abstract}
Introduction The human T-lymphotropic virus has been associated with human disease, affecting $\mathrm{CD} 4^{+} \mathrm{T}, \mathrm{CD} 8^{+} \mathrm{T}$, and $\mathrm{B}$ lymphocytes. It can cause T-cell leukemia/lymphoma and HTLV-associated myelopathy.

Case presentation A 31-year-old woman was admitted after 2 months of cramps, paraparesis, and fecal/urinary incontinence. She was diagnosed with neurosyphilis according to the cerebrospinal fluid analysis. Despite treatment with crystalline penicillin there was no recovery, and anti-HTLV-1/2 tests were positive; therefore, the diagnosis of HTLV-associated myelopathy was made. The patient rejected glucocorticoid treatment; baclofen and carbamazepine were used to treat spasticity and cramps, respectively. The patient has not had progression.

Discussion HTLV-associated myelopathy is generated by an exaggerated inflammatory response in the central nervous system with clonal expansion of $\mathrm{CD} 4^{+} \mathrm{T}$ and $\mathrm{CD} 8^{+} \mathrm{T}$ lymphocytes. There is not a specific and useful treatment; glucocorticoids can reduce inflammation, but do not improve clinical functional outcomes. There is a high prevalence of syphilis and human T-lymphotropic virus co-infection in tropical countries; however, myelopathy as the first clinical manifestation is unusual. The treatment of neurosyphilis could reduce the inflammation into the central nervous system and could decrease the progression of sequelae. This is the first case of myelopathy secondary to viral and treponemal co-infection confirmed in Colombia.
\end{abstract}

\section{Introduction}

The human T-lymphotropic virus (HTLV) was first described by Poiesz et al. in 1980 [1] in patients with cutaneous T-cell lymphoma, and later in Tumaco (Colombia) in 1981 [2]. The HTLV-1 and HTLV-2 subtypes have been associated with human disease, affecting $\mathrm{CD} 4^{+} \mathrm{T}$, $\mathrm{CD}^{+} \mathrm{T}$, and $\mathrm{B}$ lymphocytes, as well as dendritic cells and synovial cells. Cell-to-cell transmission occurs through viral synapses, extracellular viral groupings, and dendritic cell-

These authors contributed equally: Pilar Enríquez-Ruano, Cristian Eduardo Navarro

Cristian Eduardo Navarro

cenavarroc@unal.edu.co

1 Unit of Clinical Neurology, Department of Medicine, School of Medicine, Universidad Nacional de Colombia, Bogotá, Colombia

2 Grupo de Investigación en Neurología de la Universidad Nacional de Colombia-NEURONAL, Bogotá, Colombia mediated transmission. The viral ribonucleic acid integrates into the lymphocyte deoxyribonucleic acid (DNA) and can cause disease in two ways [3-5]: as an oncogene inducer that generates adult T-cell leukemia/lymphoma in 5\% of infected patients or by inducing an inflammatory response causing HTLV-associated myelopathy (HAM) in $1 \%$ of the cases [6].

The following is the description of the second case reported in the medical literature of a patient with HAM and co-infection with Treponema pallidum, and the first case reported in Colombia.

\section{Case presentation}

A 31-year-old woman from Bogotá was admitted after 2 months of painful cramps in her lower limbs, which worsened 2 weeks before, accompanied by weakness, gait limitation, hypoesthesia in patches, and fecal/urinary incontinence. Her medical records included migraine without aura, appendectomy, and right oophorectomy. There was no record of transfusion. She reported an active sexual 
Table 1 Clinical laboratory tests

\begin{tabular}{|c|c|}
\hline \multicolumn{2}{|l|}{ Blood tests } \\
\hline Creatinine & $0.8 \mathrm{mg} / \mathrm{dl}$ \\
\hline Ureic nitrogen & $14.6 \mathrm{mg} / \mathrm{dl}$ \\
\hline Sodium & $129 \mathrm{mmol} / \mathrm{l}$ \\
\hline Potassium & $4.26 \mathrm{mmol} / \mathrm{l}$ \\
\hline Chlorine & $103.6 \mathrm{mmol} / \mathrm{l}$ \\
\hline Calcium & $9.4 \mathrm{mg} / \mathrm{dl}$ \\
\hline Magnesium & $2.01 \mathrm{mg} / \mathrm{dl}$ \\
\hline Qualitative BhCG & Negative \\
\hline Leukocytes & $10,100 \mathrm{cells} / \mu \mathrm{l}$ \\
\hline Neutrophils & 4650 cells $/ \mu \mathrm{l}$ \\
\hline Lymphocytes & 4220 cells $/ \mu \mathrm{l}$ \\
\hline Monocytes & 840 cells/ $\mu \mathrm{l}$ \\
\hline Eosinophiles & 430 cells $/ \mu 1$ \\
\hline Basophiles & 50 cells $/ \mu 1$ \\
\hline Hemoglobin & $14.2 \mathrm{~g} / \mathrm{dl}$ \\
\hline Hematocrit & $40.9 \%$ \\
\hline Platelets & 251,000 cells $/ \mu \mathrm{l}$ \\
\hline Prothrombin time & $13.6 \mathrm{~s}$ \\
\hline $\begin{array}{l}\text { Activated partial } \\
\text { thromboplastine time }\end{array}$ & $25.8 \mathrm{~s}$ \\
\hline Glucose & $98.3 \mathrm{mg} / \mathrm{dl}$ \\
\hline Thyroid-stimulating hormone & $5.16 \mu \mathrm{UI} / \mathrm{ml}$ (upper limit) \\
\hline Cobalamin & $461 \mathrm{pg} / \mathrm{ml}$ (normal) \\
\hline Folic acid & Higher to $20 \mathrm{ng} / \mathrm{ml}$ \\
\hline RPR & 1:1 dilutions \\
\hline FTA-ABS & 2.4 (positive) \\
\hline HIV $1 / 2$ & Negative \\
\hline HBsAg & Negative \\
\hline Anti-core HBV & Negative \\
\hline Anti-HCV & Negative \\
\hline Anti-HTLV-1/2 (EIA) & 189.90 (reactive) \\
\hline Anti-HTLV-1/2 (western blot) & Positive \\
\hline \multicolumn{2}{|l|}{ Cerebrospinal fluid tests } \\
\hline Color & Crystal clear \\
\hline Opening pressure & $140 \mathrm{mmH}_{2} \mathrm{O}$ \\
\hline Erythrocytes & 4 cells $/ \mu \mathrm{l}$ \\
\hline Cell count & 6 cells $/ \mu \mathrm{l}$ \\
\hline $\mathrm{pH}$ & 7 \\
\hline Glucose level & $52 \mathrm{mg} / \mathrm{dl}(0.53)^{\mathrm{a}}$ \\
\hline Proteins & $58.2 \mathrm{mg} / \mathrm{dl}$ \\
\hline Gram stain & Negative \\
\hline Baciloscopia & Negative \\
\hline VDRL & Reactive \\
\hline FTA-ABS & 2.7 (reactive) \\
\hline Anti-HTLV-1/2 (EIA) & 9.9 (reactive) \\
\hline Anti-HTLV-1/2 (western blot) & Positive \\
\hline
\end{tabular}

Table 1 (continued)

Blood tests

Electrodiagnostics

Neuroconduction and electromyography of four limbs

Somatosensory, visual, and auditory evoked potentials

Normal

Integrity of the somatosensory, retinocortical, and bilateral auditory pathway

$\mu l$ microliter, $m g / d l$ miligram per deciliter, $\mathrm{mmol} / \mathrm{l}$ millimole per liter, $\mu U I / m l$ international microunits per liter, $p g / m l$ picograms per milliliter, $\beta h C G$ beta human chorionic gonadotropin, $R P R$ rapid plasma reagin, FTA-ABS fluorescent treponemal antibody absorption, $V D R L$ venereal disease research laboratories, HIV human immunodeficiency virus, $H B s A g$ hepatitis $\mathrm{B}$ surface antigen, $H B V$ hepatitis $\mathrm{B}$ virus, $H C V$ hepatitis $\mathrm{C}$ virus, $H T L V$ human T-lymphotropic virus, EIA enzyme immunoassay

${ }^{\mathrm{a} C S F}$ to serum glucose ratio

life and was on oral contraceptive pills. There was no toxic or psychoactive substance exposure. She was admitted with stable vital signs and without any disturbances during the general physical checkup; mental and cranial nerve examinations were also normal. Positive findings included proximal and distal weakness ( $3 / 5$ by Medical Research Council scale) with spasticity in her lower limbs, hyperreflexia with patellar and ankle clonus, bilateral Hoffman and Babinski signs, assisted gait, asymmetrical bilateral hypoesthesia in lower limbs without a definable sensory level, and proprioception without alterations. No signs of cerebellar or meningeal irritation were found. Given the clinical findings, a medullary syndrome was considered. Serial blood and imaging tests were requested to identify possible etiology (Table 1) (Figs. 1 and 2). Asymptomatic mild euvolemic hyponatremia was first reported without alterations in renal function; there was no leukocytosis or cobalamin deficiency. Subacute combined degeneration, spinal cord compression, spinal cord abscess, and demyelination were ruled out, but neurosyphilis, HTLV-1associated myelopathy, and HIV-myelopathy were considered in the differential diagnosis (Table 1). HIV infection was later ruled out; however, latent syphilis was confirmed and benzathine penicillin therapy was initiated (intramuscular 2.4 million units per week for 3 weeks). A cerebrospinal fluid (CSF) analysis was also conducted, resulting in high CSF proteins concentrations with a positive treponemal and non-treponemal test. Neurosyphilis was confirmed and a course of treatment with crystalline penicillin was initiated (intravenously 24 million units per day for 14 days). After a few days, anti-HTLV-1/2 antibody tests from the serum and CSF samples were examined, being positive with an index of 189.90 and 9.9, respectively (enzyme-immunoassay technique). This infection was later 


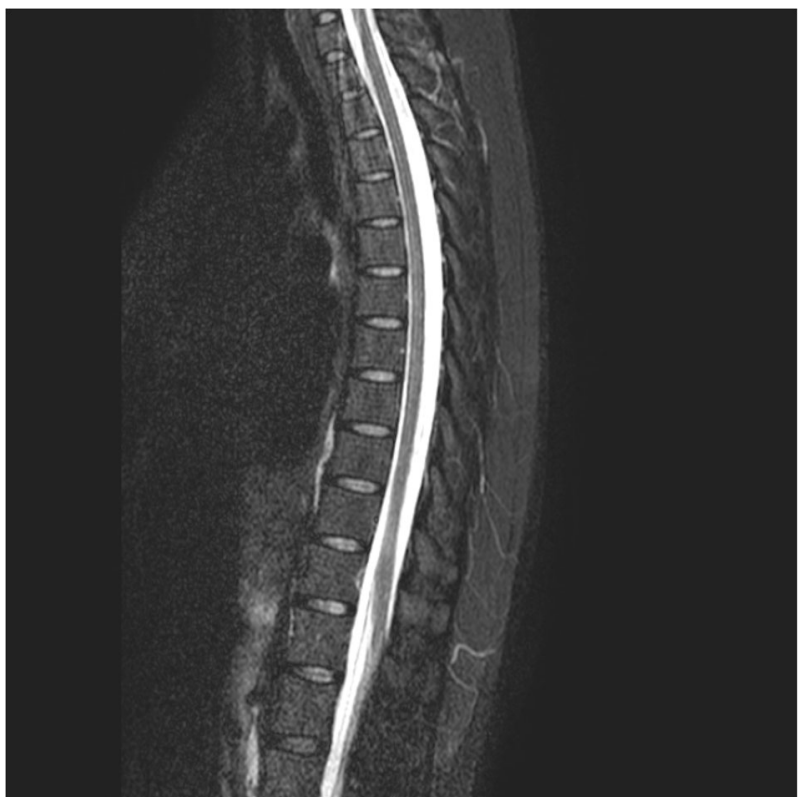

Fig. 1 Sagittal STIR (short-tau inversion-recovery) magnetic resonance image of thoracic spinal cord does not show any hyperintense lesion

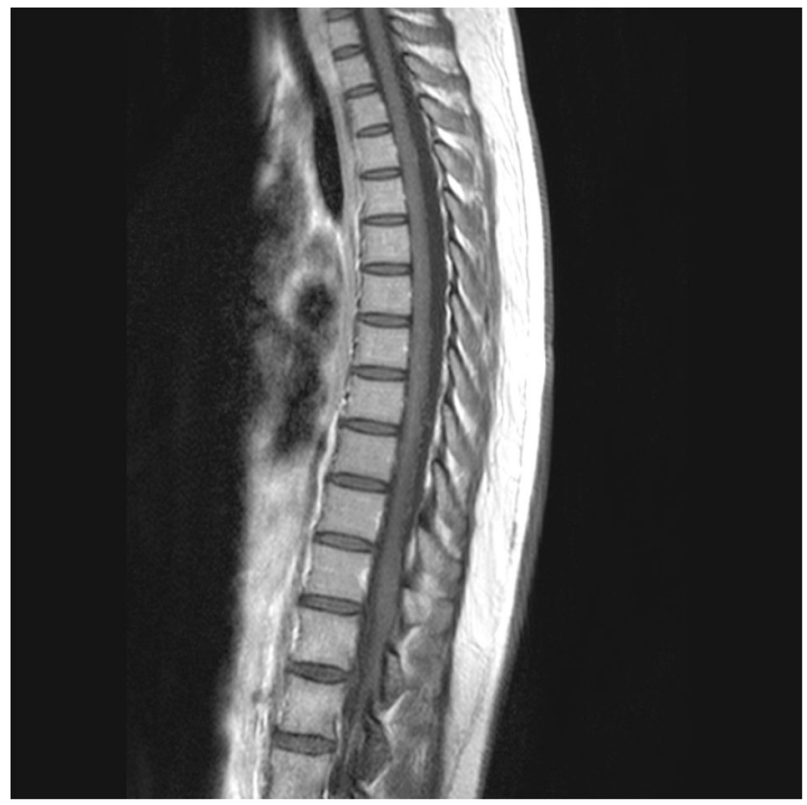

Fig. 2 Sagittal contrast-enhanced T1-weighted image of thoracic spinal cord does not show any contrast-enhancing lesion

evaluated with the western blot (positive result), and HAM was therefore confirmed. To treat her spasticity and painful muscle cramps, $10 \mathrm{mg}$ of baclofen every $8 \mathrm{~h}$, and $400 \mathrm{mg}$ of carbamazepine every $12 \mathrm{~h}$, were administered orally. Likewise, physiatry and urology examination were conducted. The patient evidenced no improvement after 14 days of penicillin treatment and HTLV was suggested as the main etiology. Therapy with glucocorticoids was offered to the patient along with explanation of potential adverse effects and she refused treatment. Currently, she has persistent weakness with functional limitation; however, she has diminished spasticity and muscle cramps.

\section{Discussion}

HAM is generated by an exaggerated inflammatory response in the central nervous system with clonal expansion of $\mathrm{CD}^{+}{ }^{+} \mathrm{T}$ and $\mathrm{CD} 8^{+} \mathrm{T}$ lymphocytes, and an increase in cytokines and chemokines that lead to infiltration of inflammatory cells in watershed circulation areas. It leads to axonal and myelin degeneration. There is no certainty of a cross response against antigens of glial cells similar to viral antigens [5, 7]. Risk factors correspond to high levels of proviral DNA and genetic predisposition (HLADRB $1 * 0101$, HLA-B*07, polymorphisms of cytokines) $[3,6]$. Transmission mechanisms are sexual (male-to-female transmission risk being 61\%) [3, 4], transfusions (20-60\%) [2], and breastfeeding (18-30\%). It is estimated that 10-20 million people are infected worldwide [6]. The highest prevalence is recorded in Japan $(10-40 \%)[6,8,9]$. Prevalence estimates for Colombia are as follows: $2-3 \%(80 \%$ asymptomatic carriers), $3.8 \%$ of patients have HAM, and 2-5\% adult T-cell leukemia/lymphoma [2, 3, 8].

HAM is progressive in adults, has an average age at onset of 40 years, and is predominant in women. Motor manifestations include gait disturbance, falls, hyperreflexia, clonus, Babinski sign, weakness, and spasticity of lower limbs (97\%). Low back pain may precede motor symptoms $(70 \%)$, and there may be paresthesia and hypoesthesia without a defined sensory level. Urinary incontinence, constipation, sexual dysfunction, and neurogenic bladder may be present $[3,10]$. The clinical picture may be associated with alveolitis, uveitis, Sjögren's syndrome, joint disease, vasculitis, cryoglobulinemia, and monoclonal gammopathy [10]. Considering the clinical presentation and Colombia as an endemic country for infection, in this case, HAM had to be included in the differential diagnosis.

An etiological diagnosis was conducted based on international recommendations where specific antibodies against the virus in blood as well as in CSF were detected. Initially, an enzyme-linked immunosorbent assay test is recommended to later confirm the resulting diagnosis through a western blot test. Detecting the provirus through a polymerase chain reaction can be useful, but in our case, we did not have this test available. The findings in the CSF included lymphocytic pleocytosis (33\%), mild-to-high CSF protein concentrations, and oligoclonal bands; these changes can be maintained for more than 10 years [3, 10]. Magnetic resonance imaging of the spinal cord is abnormal in $14 \%$ of cases, affecting the high thoracic spine with 
hyperintense signal in $\mathrm{T} 2$ sequences, contrast enhancement [3], or atrophy. In this case, there were no abnormalities in the image and the absence of these findings could not rule out the diagnosis. The differential diagnosis includes multiple sclerosis, neuromyelitis optica spectrum disorder, spinal cord compression, spinal cord abscess, hereditary spastic paraplegia, Sjögren's syndrome, subacute combined degeneration, neurosyphilis, HIV-myelopathy, and dural arterio-venous fistula. All of these diseases were ruled out in this patient, except hereditary spastic paraplegia whose clinical presentation did not correspond to this case.

Drugs such as zidovudine, lamivudine, and raltegravir have been shown ineffective in clinical trials; interferons and cyclosporine also did not have consistent results [6]. Sato et al. recently [11] evaluated the safety and pharmacokinetics of mogamulizumab, finding that periodic doses appear to be safe and decrease the proviral load in $46.4 \%$ and neopterin level in $45.1 \%$ around week 24 . On the other hand, glucocorticoids, in the first 3 years of the disease, can reduce inflammation, but do not improve clinical functional outcomes [6]. Similarly, symptomatic and rehabilitative treatment focused on the control of spasticity, neuropathic pain, and bladder and bowel dysfunction must be provided [3]. Considering the above, treatment for spasticity was provided; however, glucocorticoids were refused by the patient. Baclofen and carbamazepine were useful to treat spasticity and painful cramps, respectively.

It is possible the immune alteration generated by HTLV infection favors the development of severe cases of strongyloidiasis and tuberculosis [3, 4]. The effect of the virus in neurosyphilis has not been clarified-it is unknown whether infection with Treponema pallidum can have any effect both in the development and progression of the myelopathy or vice versa. Studies in animals have shown defects in cellular immunity with a decrease in the production of IL-2 and other activating factors of macrophages [12].

Cases such as this in the medical literature are scarce $[13,14]$. A case-control study of 183 Jamaican patients with HAM and 200 controls found a significantly higher prevalence of non-treponemal and treponemal tests in patients with HAM compared with controls $(34.9 \%$ vs $14.0 \%, p<$ $0.001)$ [15].

The patient's treponemal and non-treponemal tests were positive in blood as well as in CSF. Latent syphilis of unknown duration was considered due to the lack of records reporting sexually transmitted disease treatments. The (1) absence of clinical symptoms of spinal neurosyphilis such as tabes dorsalis or meningovascular myelitis, and (2) no improvement at the end of the entire 14 days crystalline penicillin treatment were indicators that Treponema pallidum infection was not the only cause of the disease. For that reason, the search of another etiology such as HTLV infection was necessary. It is probable that the neurosyphilis treatment helped to stop the progression of the myelopathy. Unfortunately, it is impossible to be certain whether the Treponema pallidum infection facilitated the incidence of HAM.

To conclude, this is the first case of HAM with Treponema pallidum co-infection reported in Colombia (and the second in the published medical literature). HTLV infection has become a public health problem and mechanisms to prevent it as well as properly identify in a timely basis it are needed. In patients with a clinical presentation compatible with non-traumatic and non-compressive subacute/chronic myelopathy, the possibility of infection by both microorganisms must also be considered.

Acknowledgements To the patient for allowing us to publish her case and create knowledge.

\section{Compliance with ethical standards}

Conflict of interest The authors declare that they have no conflict of interest.

Informed consent The patient granted her informed consent to publish her case and the images included within.

Publisher's note Springer Nature remains neutral with regard to jurisdictional claims in published maps and institutional affiliations.

\section{References}

1. Poiesz BJ, Ruscetti FW, Gazdar AF, Bunn PA, Minna JD, Gallo RC. Detection and isolation of type $\mathrm{C}$ retrovirus particles from fresh and cultured lymphocytes of a patient with cutaneous T-cell lymphoma. Proc Natl Acad Sci USA. 1980;77:7415-9.

2. Bermúdez-Forero MI, Berrío-Pérez M, Herrera-Hernández AM, Rodríguez-Rodríguez MJ, García-Blanco S, Orjuela-Falla G, et al. Prevalencia de la infección con el virus linfotrópico de células $\mathrm{T}$ humanas de tipo 1 y 2 en donantes de sangre en Colombia, 20012014: implicaciones sobre la seguridad de la transfusión. Biomédica. 2016;36 Suppl 2:194-200.

3. Yamano Y, Sato T. Clinical pathophysiology of human Tlymphotropic virus-type 1-associated myelopathy/tropical spastic paraparesis. Front Microbiol. 2012;3:1-10.

4. Rivera-Caldón C, López-Valencia D, Zamora-Bastidas T, DueñasCuéllar R, Mora-Obando D, Rivera-Caldón CC, et al. Infección por el virus linfotrópico humano de células T tipo 1 (HTLV-1) y paraparesia espástica. Avances y diagnóstico 35 años después de su descubrimiento. Iatreia. 2017;30:146-59.

5. Lepoutre V. Role of resident CNS cell populations in HTLV-1associated neuroinflammatory disease. Front Biosci. 2009;14:1152.

6. Bangham CRM, Araujo A, Yamano Y, Taylor GP. HTLV-1associated myelopathy/tropical spastic paraparesis. Nat Rev Dis Prim. 2015;1:15012.

7. Izumo S. Neuropathology of HTLV-1-associated myelopathy (HAM/TSP). Neuropathology. 2010;30:480-5.

8. Gessain A, Cassar O. Epidemiological aspects and world distribution of HTLV-1 infection. Front Microbiol. 2012;3:1-23.

9. Willems L, Hasegawa H, Accolla R, Bangham C, Bazarbachi A, Bertazzoni $U$, et al. Reducing the global burden of HTLV-1 
infection: an agenda for research and action. Antivir Res. 2017; 137:41-8.

10. Sato T, Yagishita N, Tamaki K, Inoue E, Hasegawa D, Nagasaka $\mathrm{M}$, et al. Proposal of classification criteria for HTLV-1-associated myelopathy/tropical spastic paraparesis disease activity. Front Microbiol. 2018;9:1-12.

11. Sato T, Coler-Reilly ALG, Yagishita N, Araya N, Inoue E, Furuta $\mathrm{R}$, et al. Mogamulizumab (Anti-CCR4) in HTLV-1-associated myelopathy. N Engl J Med. 2018;378:529-38.

12. Tseng C-TK. Sell S. protracted Treponema pallidum -Induced cutaneous chancres in rabbits infected with human T-cell leukemia virus type I. AIDS Res Hum Retroviruses. 1991;7: 323-31.

13. Carnaúba D Jr, Bittencourt A, Brites C. Atypical presentation of syphilis in an HTLV-I infected patient. Braz J Infect Dis. 2003;7:273-7.

14. Burneo JG, Carod-Artal FJ. Paraparesia espastica tropical e infeccion mixta por Treponema pallidum y HTLV-I. Rev Neurol. 2000;30:1275-6.

15. Barton EN, Morgan OS, Smikle MF, Blattner WA. Reactive serological tests for syphilis in tropical spastic paraparesis: a dilema. J Trop Med Hyg. 1993;96:172-4. 